Article

\title{
Tenure Security and Land Appropriation under Changing Environmental Governance in Lowland Bolivia and Pará
}

\section{Pablo Pacheco ${ }^{1, *}$ and José Heder Benatti ${ }^{2}$}

1 Center for International Forestry Research (CIFOR), Jalan CIFOR Situ Gede, Bogor Barat 16115, Indonesia

2 Universidade Federal do Pará (UFPA), Rua Augusto Corrêa, 01 — Guamá, Belem CEP 66075-110, Brazil; E-Mail: jbenatti@ufpa.br

* Author to whom correspondence should be addressed; E-Mail: p.pacheco@cgiar.org; Tel.: +62-251-8622-622; Fax: +62-251-8622-100.

Academic Editor: Eric J. Jokela

Received: 21 September 2014 / Accepted: 11 February 2015 / Published: 16 February 2015

\begin{abstract}
Appropriation of public lands associated with agricultural frontier expansion is a longstanding occurrence in the Amazon that has resulted in a highly skewed land-tenure structure in spite of recent state efforts to recognize tenure rights of indigenous people and smallholders living in or nearby forests. Growing concerns to reduce environmental impacts from agricultural development have motivated state governments to place greater attention on sustainable land management and forest conservation. This paper assesses the political and institutional conditions shaping tenure security and land appropriation in lowland Bolivia and the State of Pará in Brazil, and their links with environmental governance. The two cases show that clarifying and securing tenure rights is considered as the cornerstone for improving environmental governance. Thus, much attention has been given to the recognition of indigenous people and smallholder rights and to legalization of large-scale estates in agricultural frontiers, which have in turn influenced emerging conservation and environmental governance approaches. While policy frameworks share similar goals in the two cases, contrasting implementation approaches have been adopted: more agrarian in lowland Bolivia and more conservationist in the State of Pará.
\end{abstract}

Keywords: tenure security; tenure reform; land appropriation; land governance; Amazon 


\section{Introduction}

Land appropriation, either by large- or small-scale landholders associated with agricultural frontier expansion, is a longstanding occurrence in the Amazon [1,2]. This has resulted in a highly skewed land-tenure distribution that has been hard to reverse despite recent efforts from states to recognize both customary rights of indigenous people and tenure rights of traditional communities, agroextractivists, and peasant colonists who live in or nearby forests $[3,4]$. Land appropriation by individual landholders and corporate actors has taken place not only through the encroachment of public lands but also by the occupation of indigenous lands [5], and through land transactions in quite vigorous land markets. Land appropriation has often favored more capitalized and local powerful actors [6,7]. While it has in some cases threatened the livelihoods of indigenous people and traditional smallholders, its main effect has been to lock out their longer-term access to agricultural lands [8]. Interestingly, land appropriation and successive land regularization have been shaped by state policies aimed at enhancing environmental governance. Environmental policies have focused on designating public lands as conservation areas and regulating forest use and conversion in both public lands and private landholdings [9].

This paper discusses tenure security and land appropriation in the Amazon, in the context of changing environmental governance approaches based on two cases at the sub-national level. The first case is lowland Bolivia, in Western Amazon, and the second is the state of Pará in Brazil, in Eastern Amazon. These two regions, originally dominated by significant forest cover, underwent processes of frontier occupation shaped by contrasting social and economic conditions; however, both were influenced by policy approaches that shared similar concerns. Policy approaches have focused on three main issues: first, clarifying property rights to secure land ownership to individual landholders (from small- to large-scale); second, recognizing collective rights of indigenous people and traditional communities (e.g., agroextractivist, peasant farmers) to the lands they traditionally occupied; and third, protecting public forestlands from encroachment to conserve them. Land policy intercepts with environmental governance since tenure has been considered as the cornerstone for improving land and forests governance.

In the two cases, states have put in place ambivalent policies for supporting, on the one hand, small-scale farming agriculture, and on the other, agribusiness development. The scope of these policies has changed over time, although the bulk of incentives (e.g., subsidized credit, tax holidays) has targeted agribusiness [10]; investments in roads development, improved access to national and international commodity markets, and policy measures that legitimized land occupation have also benefited agribusiness [11,12]. As a result, agribusiness has expanded rapidly [13], and is currently comprised of medium- and large-scale landholdings with strong market and financial ties to national and transnational corporations that have contributed to expanding the existing capacity for primary processing, modernizing the value chains, and strengthening the linkages of specialized farmers to more distant globalized markets [14]. Access to new markets has tended to reinforce and legitimize further processes of land appropriation in the Amazon with contradictory impacts on the environment, often leading to an unequal distribution of economic benefits along the supply value chain.

Environmental concerns have changed radically during the last decades. In the past, governments subscribed to a development perspective that promoted the opening of forestlands - considered idle lands - to agriculture as a way to help increase food supply as part of a broader strategy to achieve import substitution coupled to industrialization objectives [15]. Over time, however, concerns with 
environmental impacts from agricultural development led governments to focus on reducing carbon emissions in the land-use sector to contribute to climate change mitigation targets [16]. These concerns stimulated the mainstreaming of policies aimed at changing the rules of the game for land and forest use, which have also influenced land allocation and recognition of local tenure rights. The two cases discussed here show contrasting policy approaches for enhancing environmental governance; however, both embraced the common goal of reducing environmental impacts of agricultural frontier expansion, while supporting improved land administration and more sustainable land and forest management.

The expansion of agricultural frontiers initiated in the late 1960s has led to significant forest conversion since, although it has tended to decrease in recent years due to more stringent land and forest regulations and increased law enforcement. Often, large-scale crop plantations or extensive cattle ranching have had more significant effects on forest conversion [17,18]. In contrast, smallholders have tended to adopt more diversified land-uses allowing forest regeneration [19], while in some cases they have adopted commercial agriculture as the main activity leading to forest conversion as well [20]. Encroachment of public lands and persistent deforestation has prompted important changes in environmental regulations in the 1990s, including a more active role of the state in monitoring and enforcement, as well as growing participation of civil society in the governance of timber and agri-food value chains [21,22]. These emerging regimes have led to a reduced deforestation since the mid-2000s, but with diverse success across locations. Understanding the underlying institutional arrangements and their effects is crucial for devising ways to improve landscape governance.

The two cases discussed here, lowland Bolivia and the state of Pará, have important commonalities with regard to the factors driving land appropriation and frontier expansion. However, they differ in terms of the policy approaches that were adopted to face their environmental implications. By assessing the drivers and impacts of land appropriation under two contrasting policy approaches, we contribute to a broader debate aimed at understanding what the most effective environmental governance approaches are for enhancing lands and forest governance [23]. We argue that land acquisition is a longstanding process in the Amazon whose benefits are skewed towards medium- and large-scale landholders even in the presence of tenure securitization policies recognizing indigenous people and smallholder tenure rights. Furthermore, tenure reforms are key to shaping the outcomes from changing environmental governance in Amazon frontiers, thus leading to different results in landscape governance. Our analysis is based on literature reviews, semi-structured interviews with key informants, and reviews of official statistics focusing on lowland Bolivia and the state of Pará.

This paper is organized into six sections, including this introduction. The second section introduces our analytical framework with focus on understanding land appropriation, property rights, and frontier expansion. The third and fourth sections discuss the lowland Bolivian and Pará cases, respectively. Most of our attention, when looking at these two cases, is placed on the history of land appropriation and the main changes in the land and forest policy framework and environmental governance. The fifth section compares the two cases and discusses their main commonalities and differences. Finally, the sixth section pulls together this paper's main conclusions. 


\section{Land Appropriation, Property Rights and Frontier Expansion}

Land appropriation and land regularization are contested topics. Different perspectives offer insights to understand the way in which tenure security rights influence land and forest use; the processes for securing rights; the way in which these rights are acquired and legitimized; and how tenure rights tend to influence land appropriation and subsequently frontier expansion. This section discusses three main questions in light of three different disciplinary perspectives: neo-classical economics, neo-institutional economics, and political ecology. These perspectives answer these issues differently (see Table 1), which has implications for the debate on how to enhance environmental governance.

Table 1. Approaches to property rights formalization with implications for environmental governance.

\begin{tabular}{|c|c|c|c|}
\hline \multirow{2}{*}{ Key Ques } & \multicolumn{3}{|c|}{ Views from Three Different Disciplinary Perspectives } \\
\hline & J Fonomics & Neo-Institutional Economics & Political \\
\hline $\begin{array}{l}\text { What is the } \\
\text { importance of } \\
\text { clarifying tenure } \\
\text { and securing } \\
\text { property rights? }\end{array}$ & $\begin{array}{l}\text { Land becomes a collateral, } \\
\text { and clear and secure tenure } \\
\text { tends to value land assets } \\
\text { and promote secure } \\
\text { long-term investments. }\end{array}$ & $\begin{array}{l}\text { Clarifying the bundles of } \\
\text { rights - ranging from authorized } \\
\text { user, to claimant, to proprietor, } \\
\text { and to owner - affects the } \\
\text { transaction costs influencing the } \\
\text { behavior of landholders with } \\
\text { regards to resources use. }\end{array}$ & $\begin{array}{l}\text { Land regularization } \\
\text { reduces conflict over } \\
\text { resources, but the process } \\
\text { may threaten more } \\
\text { vulnerable groups and } \\
\text { benefit powerful } \\
\text { actors with a relative } \\
\text { bargaining advantage. }\end{array}$ \\
\hline $\begin{array}{l}\text { What is the } \\
\text { influence of clear } \\
\text { and secure tenure } \\
\text { rights on land-use } \\
\text { decisions? }\end{array}$ & $\begin{array}{l}\text { Secure tenure promotes } \\
\text { long-term investments } \\
\text { with better outcomes on } \\
\text { land-use optimization and } \\
\text { risk management. }\end{array}$ & $\begin{array}{l}\text { Alienation rights combined } \\
\text { with exclusion rights produce } \\
\text { incentives for owners to make } \\
\text { long-term investments } \\
\text { in the improvement of their } \\
\text { production systems. }\end{array}$ & $\begin{array}{l}\text { It is difficult to achieve } \\
\text { secure tenure since rights } \\
\text { are contested over time, } \\
\text { and land-use outcomes } \\
\text { depend on who is the } \\
\text { actor holding the rights. }\end{array}$ \\
\hline $\begin{array}{l}\text { How does securing } \\
\text { tenure rights affect } \\
\text { the dynamics of } \\
\text { land appropriation } \\
\text { and frontier } \\
\text { expansion? }\end{array}$ & $\begin{array}{l}\text { Optimizing agents react } \\
\text { to pull incentives, and } \\
\text { to market prices. Secure } \\
\text { tenure contributes to } \\
\text { the development of } \\
\text { financial markets. }\end{array}$ & $\begin{array}{c}\text { Recognizing rights to } \\
\text { existing land uses may } \\
\text { contribute to stabilizing frontiers } \\
\text { because they are able to improve } \\
\text { governance conditions. }\end{array}$ & $\begin{array}{l}\text { Land competition, in a } \\
\text { context of asymmetric } \\
\text { power relations and weak } \\
\text { states, promotes a } \\
\text { sustained process of } \\
\text { frontier occupation. }\end{array}$ \\
\hline
\end{tabular}

As summarized in Table 1 above, the theoretical perspectives depicted here acknowledge the complexity of land tenure in contexts where competing demands and institutions shape land access and legitimization of tenure rights. These views differ on the three key questions above, specifically on the importance of clarifying and securing tenure rights, the way in which these rights influence land-use decisions, and how acquired tenure rights influence the dynamics of frontier expansion.

With regards to the first question, a neo-classical economic perspective considers that securing land rights contributes to the development of land and financial markets, with significant effects in fostering investments. Providing tenure security in the long term, administered in a cost-effective way through institutions that combine legality with social legitimacy, can be achieved in a variety of ways, depending 
on the situation [24]. In this view, clear property rights provide landholders with the certainty to undertake long-term investments in their farms, which might lead to better outcomes on land-use optimization and risk management. This may have contradictory effects on forests, depending on the opportunity costs of alternative land uses. Securing tenure rights, however, may result in ambiguous outcomes in frontier expansion, which depends on market conditions of other factors (e.g., land, labor and capital). In this view, rational economic agents, guided by objectives of profit maximization react to pull incentives in the frontier, mainly investment opportunities determined by market prices; this often leads to converting forest to land uses that result in higher profits [6]. For example, frontier expansion is shaped by the availability of cheap land in the frontiers but scarcer labor and capital [25]. In many cases, land uses under commercial crops, from an economic standpoint, tend to work against forest conservation since these land uses tend to be more profitable [26].

The neo-institutional economic views consider that property rights are defined not only by formal regulations but also by social norms. Both formal rules and social norms configure the economics of transaction costs that determine who legitimizes access to lands, such as the costs of planning, adapting, and monitoring under specific institutional settings [27-29]. Property rights are designed to lower fixed transaction costs by excluding others from the use of scarce resources [30]. This view stresses the importance of distinguishing between diverse bundles of rights (i.e., access, withdrawal, management, exclusion, alienation) [31]; thus, land regularization efforts should aim at unfolding these bundles of rights to clarify who has what type of rights to which resources. Neglecting these bundles of rights could lead to increased transaction costs, raise land conflict, and enlarge uneven access to resources [32]. In this view, more secure rights would favor long-term investments leading to improved resource management systems where the benefits exceed the costs invested in securing those rights. Well-defined boundaries also facilitate management of common pool resources and sustain collective action [33-36]. Recognizing tenure rights and securing them may contribute to stabilizing frontier expansion due to the importance of clear property rights on excluding outsiders, providing incentives to invest in land improvements [37,38].

Political ecology provides a more critical view on land rights formalization. This perspective argues that property rights are embedded in social relationships shaped by asymmetric power, thus efforts to secure tenure may favor those social groups with a relative bargaining advantage and likely threaten more vulnerable groups [39]. In this view, formalization of tenure rights, in contexts of uneven power relationships and market asymmetries, would lead to increased conflict, which is associated with frontier occupation where more powerful groups, with greater political influence, might take advantage of the process [40]. Furthermore, achieving secure tenure is difficult since property rights are continuously contested over time. Tenure security depends on the actors being able to legitimize and protect their rights, and resultant land use depends on the actors holding those rights. The latter is also influenced by several other structural conditions such as access to institutional rents, public resources and incentives [1]. Others suggest that where states promote a transition towards private property rights through registration and titling programs, land markets develop outside the legal frameworks, and tension and conflict emerge, leading to land concentration in the hands of powerful groups [41].

Significant efforts for clarifying and securing tenure rights have been undertaken in many developing countries where important processes of land appropriation occur in frontier situations. This is the case of lowland Bolivia and the State of Pará, Brazil. In these two cases, tenure reforms are taking place in 
the context of important efforts to improve environmental governance that contributes to objectives of forest conservation while also enabling agricultural and rural development. We assess the dynamics and implications of land regularization in these two cases in light of the three disciplinary perspectives mentioned above. The main aim is to understand which policy approach has greater potential to deliver tenure security benefits in the context of improved environmental governance.

\section{Land Struggles and Tenure Reforms in Lowland Bolivia}

\subsection{State Policy and Land Appropriation in Lowland Bolivia}

Lowland Bolivia embraces an area of about 80 million ha in the northern and eastern portions of the country [42]. The state was largely absent from lowland Bolivia from the colonial period until the mid-1950s. The most important event during the late 19th century was the occupation of the upper Amazon stimulated by a growing international market for rubber that fostered large-scale land estates claimed by a handful of investors [43]. This occupation faced strong local resistance from indigenous populations whose lands were confiscated and who ended up working in the rubber estates [44]. Simultaneously, in the lower Amazon, some Catholic religious orders stimulated the creation of missions with the main goal to concentrate indigenous populations in settlements that co-existed with traditional ranches [45].

The National Revolution, initiated in 1952, was a major political event. It shifted power to a populist government that attempted to eradicate huge social disparities through nationalization of the mining industry and agrarian reform. In lowland Bolivia, the emerging government supported commercial agricultural expansion [46,47]. Local elites, close to the government, benefited from a largely corrupt and inefficient process of land allocation that lasted during the following two decades until the early 1980s. To a large extent, this policy of allocating tenure rights to medium-size and large-scale landholdings initiated a process of land concentration on what used to be considered public lands. This was linked to a broader policy of developing agriculture in the context of import substitution goals [48].

The latter process was supported by road constructions connecting the expanding agricultural frontier in the lowlands with the main capital cities in the highlands (i.e., La Paz, Cochabamba). It stimulated expansion of crop production - mainly beef, rice, sugarcane, and cotton - through cheap credit and establishment of sugar cane mills to supply the domestic market. Yet, the latter was rapidly saturated with a relatively small amount of land converted to agriculture, and the sector had difficulties exporting the surplus production [42]. This did not impede local elites from taking over lands with speculative purposes given the interest in logging that evolved stimulated by the opening of roads for oil exploration. In the 1960s, logging was undertaken through selective harvesting of a few key valuable species to supply mainly the domestic market, and it moved northwards following road development [49]. Road development prompted the arrival of settlers to northern Santa Cruz and Chapare, a process that was initially stimulated through state-sponsored projects, which were followed by intense spontaneous immigration originating in the highlands. In the late 1970s, a new colonization zone, with state support, opened in northern La Paz, which attracted an important number of spontaneous settlers [50,51].

The 1970s coincided with the arrival of military regimes that used land allocation as a patronage mechanism to repay political favors [52]. A Forest Law, issued in 1976, allowed the state to allocate 
20 million ha to private companies for logging, even if these contracts overlapped with indigenous claims or private landholdings. According to available estimates, by the early $1990 \mathrm{~s}$, about $70 \%$ of forest concessions overlapped with other claims, including protected areas whose creation began in the late 1980s [53]. At that time, forests belonged to the state, which granted rights to the timber industry through short- and long-term contracts, and individual landholders had no legal rights to harvest them. The forest regulations requiring the implementation of forest management plans were largely ignored by the timber industry, which exerted a strong influence in political circles [54]. As a result, the most valuable timber species (mahogany and cedar) were almost exhausted in the lower Amazon. Thus the timber industry kept moving northwestward in the late 1980s, following new road development, as a way to reproduce a scheme of selective logging [49]. Yet timber operations clashed with indigenous populations that began to claim tenure rights on traditional territories [55]. This was favored by a process of democratization and ended up with the recognition of a few indigenous territories in 1990.

The structural adjustment policies implemented in the mid-1980s, mainly as a response to the country's acute economic crisis since the early 1980s, created new conditions for economic growth associated with trade liberalization for agribusiness and timber industry development. These policies had the effect of expanding pressures on forests associated with soybean expansion and commercial logging [56]. Soybean expansion influenced Brazilian investors who imported technology developed for the Cerrado region, purchased cheap land from those who had acquired it during the military regimes, and benefited from a trade regime that reduced import tariffs in member countries of the Andean Community, which were the primary soybean importers [12,57]. Until the 1980s, timber exports chiefly supplied markets in neighboring countries (e.g., Argentina); larger investments in processing helped the timber industry to target the American and some European markets [49].

In the late 1980s, surprisingly, the protected areas expanded in the country associated with broader development discourse that embraced conservation goals as part of government policies for supporting sustainable development [58]. In this context, several protected areas were created in forestlands not precisely threatened by external pressures at that time, which helped conservation co-exist with agricultural expansion [9]. In a few cases, protected areas overlapped with indigenous lands, but local populations obtained greater decision-making powers on the management plans in these conservation areas [59]. The increasing land conflict, particularly in the zones where agribusiness expanded and where timber companies with forestry permits clashed with indigenous people's demands, led to a major restructuring of the land administration systems.

In 1996, a new Land Law (No. 1715) adjusted the public system to support land administration and initiated land regularization in Bolivia involving a process of verification, registration, and titling. That same year, a new Forest Law (No. 1700) was issued aimed at introducing a system of long-term forest concessions along with new regulations to stimulate sustainable forest management [60]. These two laws set the foundations for adopting new concepts of environmental governance in the country.

\subsection{Evolving Legal Frameworks for Land and Tenure Rights Allocation}

The Land Law and Forest Law issued in 1996, introduced substantial changes to the policy framework for land and forest administration in Bolivia. There were four main areas of intervention. The first aimed at land regularization with a dual objective of clarifying existing individual rights and recognizing 
customary rights for indigenous people, which was accompanied by efforts to clarify forest rights in both public and private lands. The second was a forest reform to promote the adoption of sustainable forest management by imposing a series of instruments in both public and private lands. The third introduced an institutional reform in the forestry sector, which was accompanied by transferring some resources and responsibilities to municipal governments. The fourth adopted territorial planning through the implementation of land-use plans at the national, departmental, and municipal levels. These four areas of interventions were aimed at supporting to achieve sustainable land and forests management [61].

Land regularization involved two somewhat contradictory processes. The first aimed at clarifying customary rights of indigenous communities, mainly from those groups threatened by logging and large-scale agriculture, as well as formalizing the rights of individual landholders, both small- and large-scale [62]. A process of demarcation, registration, and titling was put in place for both cases, with the goal of establishing rural cadastres. The second process was devised to clarify usufruct rights in public lands, mainly by converting forestry contracts - most of them issued in the 1970s - into a new system of long-term forest concessions with rights lasting for 40 years. It also introduced a scheme of social concessions through which available public forestlands could be granted to informal local loggers. In addition, land- and forest-tenure rights were merged so that individuals or communities could enjoy exclusive forest use rights within the lands granted to them. Furthermore, new regulations were issued for concessionaries, landholders, and communities using forests with a commercial purpose [61].

As mentioned, land regularization had the main objective to solve the growing disputes linked to emerging claims of indigenous people to formalize their tenure rights. The Land Law of 1996 recognized the Original Community Lands (TCO, by its acronym in Spanish). These indigenous territories were demarcated based on assessments of the amount of land required by different indigenous groups to make a living and fulfill their needs when following their customary practices of resource management [63]. This was a highly contentious political process since a portion of the lands claimed by indigenous people was already encroached by loggers and ranchers. The indigenous groups claimed around 19.5 million ha in the lowlands. The state, with help from international donors and consultants, undertook the regularization of these community lands through a more expeditious process of regularization. To date, 13.8 million ha have been titled as indigenous territories and additional 805 thousand ha as community lands for indigenous people (Table 2). Indigenous people were granted the right to undertake forest management in their titled lands, and there are about 1.7 million ha under formal management [64].

While there are no official numbers, an estimated 43 million ha would have been granted to medium- and large-scale landholders and 3.7 million ha to smallholders in lowland Bolivia between 1953 and 2002 [65]. Due to the existence of fraudulent land claims, land regularization included the legal evaluation of these claims - many of which were still in process - followed by in-situ verification of boundaries [66]. The main criterion adopted for land regularization in individual landholdings was compliance with the social and economic functions of land (FES, by its acronym in Spanish), which replaced the social function of land, a concept embraced during the agrarian reform in the 1950s. The FES was relatively broadly defined, including not only agricultural but also forest and conservation activities. However, in practice, agricultural land use remained as the main criterion to formalize tenure rights when assessing FES compliance. According to available data, about 16.8 million ha are in process or have been titled to medium- and large-scale landholders and 2.8 million ha to smallholders. About 11.9 million ha were pending regularization, and an important portion has likely been occupied by 
medium- and large-scale landholders (Table 2). Furthermore, 10.7 million ha have been identified as public lands, part of which constitute lands that were reverted back to the state after landholdings FES evaluation [67].

Table 2. Land tenure and forest rights in lowland Bolivia.

\begin{tabular}{|c|c|c|}
\hline Lands by Type of Rights & Total Land (Thousand ha) $^{a}$ & $\%$ \\
\hline Total area lowland Bolivia & 79,706 & 100.0 \\
\hline \multicolumn{3}{|c|}{ Lands by type of actor } \\
\hline Small-scale landholdings & 2,796 & 3.5 \\
\hline Medium- and large-scale landholdings & 16,787 & 21.1 \\
\hline Community lands & 8,020 & 10.1 \\
\hline Indigenous territories & 13,870 & 17.4 \\
\hline Public land identified & 10,673 & 13.4 \\
\hline No land regularization & 11,942 & 15.0 \\
\hline \multicolumn{3}{|c|}{ Lands classified as conservation areas } \\
\hline Protected areas & $10,425^{b}$ & 13.1 \\
\hline \multicolumn{3}{|c|}{ Public lands with forest rights } \\
\hline Timber forest concessions & 3,448 & 4.3 \\
\hline Non-timber forest concessions & $1,745^{c}$ & 2.2 \\
\hline
\end{tabular}

Sources: These estimates are only referential and are produced based on information from official information provided by the National Land Agency (INRA), but do not constitute official estimates. ${ }^{\text {a }}$ Based on non-published reports provided by INRA as of 2014 unless indicated otherwise; ${ }^{b}$ Based on protected areas from the National Service of Protected Areas (SERNAP), do not include areas under protection superposed to other tenure rights; ${ }^{\mathrm{c}}$ Corresponds to expected rights on state lands where Brazil nuts are collected.

The Forest Law of 1996 prompted a drastic reduction of the land under control of timber companies from 20 million ha to 5.4 million ha in the mid-1990s. This reduction was mainly due to the change of the stumpage fee from a volume- to an area-based system where companies had to pay USD 1 per ha. As result, companies kept only the most productive forests they were able to manage effectively [61]. In spite of this, timber companies did not pay the forest taxes as expected; yet the state forest agency did not follow administrative procedures to cancel these concessions, assuming that public forests could be more threatened without those concessions. By Decree No. 27024 in 2003, forest fees were applied only to the annual intervened area plus for the cost of forestry regulations; the latter was determined as an additional tariff for forest users to pay in order to support the functioning of the forest state agency [68]. The forest concessions have since shrunk to about 3.5 million ha due to encroachment, mainly from smallholder colonists, and the fact that some forest concessionaries were returned to the state and others were reduced in area. Out of the forest concessions, about 602,000 ha were granted to local forest user groups (ASL, by its acronym in Spanish) as social forest concessions [61].

Large-scale land estates in the upper Amazon held about 3 million ha based on traditional possession that some individuals retained in this region but with no formal contracts with the state as result of juridical gaps. Nonetheless, this amount has gradually decreased to 1.8 million ha due to the difficulty these landholders had to keep their forestland claims. These land estates, more commonly known as barracas, were traditionally dedicated to the extraction of non-timber forest resources - mainly Brazil nuts after the collapse of the rubber economy in the mid-1980s [69]. In the 2000s, this region experienced 
an intense land conflict due to the significant resistance of communities and smallholders to the attempt of a small but very politically influential group of people to appropriate most of the forests in the upper Amazon to supply a vigorous Brazil nut industry. Land regularization was based on the criterion that each rural family had to access a total of 500 ha to make a living from harvesting forest resources. Interestingly, land was titled to communities rather than individual landholders [70].

Two institutional reforms, complementary to land regularization, were political decentralization and a system of territorial planning based on land-use zoning (PLUS, by its acronym in Spanish). Political decentralization expanded responsibilities for local development to municipal governments, as well as increased resources transferred from the central state. The Forest Law also stimulated the transfer of resources and responsibilities to municipal governments with regard to forest planning, monitoring of illegal crime, and provision of public services to forest users [71]. The new system was financed with resources coming from both forest management and clear cutting fees. Municipalities were supposed to create technical units to implement their new functions, and prefectures (departmental governments) were delegated basic functions of forestry research and extension, and support for municipal forest units. These reforms did not work as expected since prefectures and municipalities did not have enough incentives to invest in monitoring, and because of its adverse political impact on local governments' legitimacy [72].

Territorial planning was adopted in the mid-1990s following policy goals to promote more sustainable agricultural development. By the early 2000s, all departments had completed a PLUS, and it was supposed to be followed by the development of similar land use plans at the municipal level. However, municipalities did not find the financial resources available for territorial planning, except a few cases supported by donors. When a PLUS was completed, it involved strong political negotiation among different stakeholders, which biased outcomes [73]. In addition, land-use planning at the farm level (POP, by its acronym in Spanish) was introduced [74]. It is noteworthy that the legislation and instruments mandating territorial planning were largely neglected when the Morales' administration came to office in 2006. This administration stimulated a few changes in the tenure reform, but did not make significant changes to the procedures described above [75].

\subsection{Current Land-Tenure Administration in Lowland Bolivia}

Land and forest reforms in the mid-1990s were framed under a broader neo-liberal approach, and were heavily criticized by the Morales' administration, which adopted a discourse favoring an "Agrarian Revolution" in the country. This revolution, however, was limited to the approval of an Adjusted Land Law (No. 3545) in 2006 as the main attempt to reform the land regularization process initiated by the Land Law in 1996. Law No. 3545 changed the mechanisms for redistributing public lands, mainly to speed up the titling process of TCOs, and make possible the expropriation of some unproductive landholdings to distribute them to less favored rural people. The latter law also cancelled the social forestry concessions system, and mandated that all available public lands - including forestlands - should be distributed to communities or landless people [75]. Complementary norms recognized the scheme of forestry settlements, suggesting that forest extraction should be the main use, yet the latter norms were not implemented in practice. 
About 6 million ha of undisputed public lands were identified to be allocated to communities [76]. The Adjusted Land Law again redefined the FES to address compliance of only agriculturally productive activities; it thus excluded conservation criteria due to concern that advocating conservation goals would justify the ownership of large-scale landholdings. This administration has promoted collective titling in the newly distributed lands and remaining indigenous claims through the establishment of the so-called Original Indigenous and Peasant Territories (TIOC, by its acronym in Spanish) as the prolongation of the TCO scheme. This figure was included in the new National Political Constitution - approved in 2009. Among other things, the new Constitution prohibits multiple allocations of state land to the same physical or juridical person, and establishes a maximum limit for rural landholding of 5,000 ha. These dispositions do not apply retroactively. It is noteworthy that many large-scale landholders in lowland Bolivia have already fragmented their landholdings or placed them in the name of another person and family members as a way to avoid reversion [67].

The forestry regulations have not undergone any major change during the Evo Morales' administration [49]. Main changes were the reform of the state forestry agency, whose director was elected by the National Congress, and made it depend on the Ministry of Rural Development as a way to exert more control. Self-regulation was introduced to support decision-making in the community (DS. 29643, 2008), as well as some complementary norms to regulate the role of auxiliary agents in forest management (RA. 106/2011); a digital forestry permit (RA. 107/2011) was also instituted to enhance effectiveness of the forestry control. The capacity for monitoring and control of the forest state agency is quite limited, but it has again concentrated these functions at the central level, eroding progress achieved through forestry decentralization [49]. The most relevant change was the approval of a law to support food production and forest restitution (Law No. 337, 2013); this promotes agricultural expansion since it legalized illegal clearing between 1996 and 2011 through affiliation to a food production program and with the commitment to restore $10 \%$ of affected forest cover, in addition to recovering areas legally classified for protection. The new regulations set a fine of USD 60 per illegally deforested hectare in farms larger than 50 ha [75].

\section{Public Lands, Tenure Struggles, and Land Administration in Pará}

\subsection{State Policy and Land Appropriation in Pará}

The Brazilian Amazon embraces about 500 million ha, most of which are covered with evergreen tropical forests, out of which a quarter comprises the State of Pará, about 120 million ha. The process of land occupation in the Brazilian Amazon dates from colonial times associated with economic interests from merchants that moved into the Amazon to extract the so-called drogas do sertão [77,78]. The latter was accompanied by the actions of several Catholic orders to convert indigenous people who were traditionally established in those lands. Although the region had been partially occupied since colonial times, and had some federal programs implemented during the 1950s such as the Plan for Economic Valorization of the Amazon, it was relatively isolated until the 1960s; at that point, the region began to be included in planning policies, leading towards its integration into the broader Brazilian economy. This isolation facilitated the emergence of strong local elites, much of whose power was based on the 
appropriation of large-scale estates associated with the remaining extractive economies, mainly rubber and Brazil nuts, and incipient cattle production supplying local markets [78].

In the 1960s, the federal government increased its presence in the State of Pará through legal measures that gradually increased its jurisdictional power in the Amazon. It did this under a political system controlled by the military, which ruled the country until 1980. The military regimes embraced industrialization objectives in the context of an import substitution policy [79]. The main priority was the Amazon integration into the rest of the country based on the premises of maintaining internal national security $[80,81]$. There was an excessive centralization of power during those times that permeated different realms of society with strong and longstanding implications in the Amazon [1,82].

Some key policy measures in the Brazilian Amazon focused on land allocation and road development. The most significant decision was the designation of all public lands as belonging to the federal state, thus limiting enormously the control of the federated states on public lands within their jurisdictions $[83,84]$. The latter was accompanied by expanding the road network, mainly the construction of the Belem-Brasilia Highway. In addition, public lands were granted to companies from southern Brazil and incentives were provided to support the expansion of extensive cattle beef production [84]. These policies were incubated under a notion of "open frontier" where lands - considered as idle and unproductive - had to be developed [85]. These different policies fostered rapid land occupation in the State of Pará [86]. This process was associated with extensive fraud, and no preventive measures were adopted to manage tenure uncertainties or conflicts with pre-existing rights.

The first Program of National Integration (PIN I, by its acronym in Portuguese) began in the late 1960s. It involved the construction of some road corridors and the establishment of directed colonization programs, and settlements at the road margins, as a way to absorb smallholders expelled due to agricultural modernization in other zones [87]. This plan faced high rates of turnover associated with several factors, including adverse agro-ecological conditions and lack of assistance [88]. Many of the colonization projects were taken over spontaneously with limited state assistance, often in situations of conflict [80]. In 1974, a second phase of this program (PIN II, by its acronym in Portuguese) established some development poles to promote agricultural expansion, mainly beef cattle, associated with credit lines and fiscal incentives for large-scale projects under the support of the Superintendence of Amazonian Development and the Bank of Amazonia [25,89,90]. The combination of state incentives, along with cheap land, led to a rapid land occupation by large-scale corporate ranches [91]. Nonetheless, in tandem, the opening of the frontier also stimulated the arrival of medium-scale ranchers who were able to benefit from available cheap land and expanding infrastructure [92].

The 1980s saw a relatively important arrival of immigrants that stimulated land occupation in the eastern state along the Belem-Brasilia and the Transamazon Highways [93]. This led to development of extensive large-scale cattle ranching, largely promoted by cheap credit and fiscal incentives [94]. In many cases, land occupation was driven by speculation from landholders wanting to capture the institutional rents (mainly credit and tax breaks) provided by the Federal State. The latter resulted in severe land conflicts mainly in southern Pará between large-scale ranchers (who acquired formal titles of land they wanted to occupy) and local people (whose rights were ignored by the state) [1].

The late 1980s witnessed a move away from centralized planning policies imposed by the military in the context of a return to democracy and the adoption of neo-liberal views of development. The new constitutional order led to important changes in the legal framework that affected the process of spatial 
organization for the Amazon, including the State of Pará, and the underpinning power relationships. The Federal State ended the territorial intervention of the Amazon region in 1987, thus transferring lands not registered under its control to federated state governments [83]. Furthermore, in the early 1990s, the first policies to protect forests and indigenous lands were put in place, thus creating some institutional barriers to the expansion of the agricultural frontier. The Pilot Program for the Conservation of the Brazilian Tropical Forests (PPG-7, by its acronym in Portuguese) was the main environmental policy implemented in the 1990s aimed to halt deforestation in the Brazilian Amazon through the promotion of sustainable practices for natural resources management. However, this program did not achieve its expected outcomes. Nonetheless, it contributed to the demarcation of indigenous lands and conservation units in the hands of the federal government [95]; this indirectly helped reinforce the role of the central state in administration of the extensive forestlands, and the resources contained in these lands.

Attempts to mainstream the environmental policy in the Amazon were made through the creation of protected areas and the promotion of sustainable forest management, and also with the adoption of economic-ecological zoning as the main planning instrument for territorial development. These policies intercepted with plans to promote economic growth through favoring large-scale investments in the region through the Brazil in Action plan (1996-2002) [96] and the Growth Acceleration Program launched in 2007. These plans privileged the expansion of infrastructure to promote the development of the agribusiness sector to supply expanding global markets [96] in the context of a broader project to connect the Amazon region with overseas markets emerging in Asia [97]. The latter uncovered a dual policy for the Amazon aimed to support developmental goals, on the one hand, and environmental protection, on the other. This policy ambiguity was the backdrop of intense land-tenure struggles in the Amazon, mainly in the State of Pará, where cattle ranchers, smallholders, traditional communities, and indigenous people, as the main actors of rural society, struggled to consolidate their tenure rights [98].

\subsection{Evolving Legal Frameworks for Land and Tenure Rights Allocation}

The agrarian and environmental legislation in Brazil is relatively complex. It began with the approval of the Land Law (No. 4.504/1964) followed by the Forest Code (No. 4.771/1965), the National Environmental Policy (No. 6.938/1981), the Law of Forest Crimes (No. 9.605/1998), the National System of Conservation Units (No. 9.985/2000), the Law of Public Forests (No. 11.284/2006), the Law of Land Regularization (No. 11.952/2009) and the new Forest Code (No. 12.651/2012). In addition, the Federal State established several programs to promote environmental protection, with a strong focus in the Amazon. It is worth highlighting the Action Plan for Deforestation Prevention and Control in the Legal Amazon (PPCDAm, by its acronym in Portuguese) approved in 2004, which included goals of territorial zoning, environmental monitoring and control, and promotion of both sustainable activities and the Plan for Sustainable Amazon (PAS, by its acronym in Portuguese) released in 2008. The latter delineates a strategy for promoting sustainable economic development, simultaneously embracing conservation goals and involving the different levels of government. The PPCDAm and PAS both constituted serious attempts to mainstream environmental concerns into development policy.

This legal framework was accompanied by several complementary and regulatory norms that provided the necessary instruments for land tenure regularization and recognition of rights to the different actors in the Brazilian Amazon (i.e., indigenous populations, traditional communities, 
smallholders, largeholders) across different ranges of tenure regimes (i.e., ownership in individual or collective agricultural and forestlands, conservation units for biodiversity protection, concessions for forest management or conservation). Nonetheless, these policies succeeded in better defining policies for recognition of tenure rights to indigenous people, as well as the demarcation and management of conservation units, which include multiple sub-categories. Today, indigenous territories and protected areas embrace 31.8 million ha in the whole state supported by a large number of state organizations created for this purpose; the analysis of their role is beyond the scope of this paper [99] (Table 3).

Table 3. Land tenure and forest rights in the State of Pará.

\begin{tabular}{ccc}
\hline Lands by Type of Rights & Total Land (Thousand ha) & \% \\
\hline Total area State of Pará & 124,768 & 100.0 \\
\hline Lands by type of actor & & \\
Small-scale landholdings & 6,073 & 4.9 \\
INCRA settlements & 21,255 & 17.0 \\
Medium- and large-scale landholdings & 34,022 & 27.3 \\
Quilombos & 455 & 0.4 \\
Public lands & 24,953 & 20.0 \\
Others & 2,961 & 2.4 \\
\hline
\end{tabular}

Lands classified as conservation units

Federal extractive reserves (RESEX $\quad 4,404 \quad 3.5$

Reserves of sustainable development (RDS) $\quad 64 \quad 0.1$

Agroextractive settlements (PAE) $\quad 3,165 \quad 2.5$

Indigenous territories $\quad 27,368 \quad 21.9$

Forest rights in public lands

Forest concessions $48 \quad 0.0$

Sources: These are referential estimates produced based on official information provided by ISA [99], ITERPA [100], and INCRA [101].

Land regularization of individual rights in lands outside indigenous territories and conservation units is the most sensitive land-tenure issue. These areas comprise about 61.4 million ha (Table 3). Two of the main concerns revolve around the Law of Land Regularization of 2009. First, the law could allow recognition of rights to lands acquired by illegal means (i.e., through encroachment of public lands, which has been quite common in the State of Pará, as well as in the Amazon as a whole [80]). Second, the law could reinforce expectations of encroachers or people claiming land-tenure rights that a new land regularization might take place in the future. This law, however, responds to a new political context where a primary goal is to reduce land encroachment and land speculation. This is aligned with simultaneous efforts to reduce pressures of deforestation. Thus, forest conversion is no longer the main criterion to justify land ownership but the socio-environmental function of the property.

In this light, one of the main goals of the land regularization policy was to identify both individual and community landholders, as well as to identify and designate existing public lands. This has two complementary objectives: halting expansion of the agricultural frontier over forestlands to contain deforestation and protecting the remaining forestlands to maintain their environmental services. About one-fifth of total lands in the State of Pará (24.9 million ha) constitute public lands, a portion of which 
was not granted to individual landholders during the 1970s and 1980s by the Federal State. Nonetheless, since most of those lands are likely occupied, the issue becomes to identify whether those rights are legitimate and, if so, to formalize them. An associated issue relates to the equity implications associated with rights formalization, since most lands were encroached by large-scale landholders.

As stated before, the agrarian reform process moved forward amid concerns for supporting sustainable development and social equity to revert a process of environmental degradation associated with extensive land concentration. From 2003 to 2010, in the State of Pará, 21.3 million ha were allocated to smallholders through the creation of smallholder settlements; along with lands granted to smallholder colonists, 27.3 million ha were put in the hands of smallholders (Table 3). Despite this, agrarian reform was not able to reverse significant existing land concentration [102]. There is only one provision in the current agrarian legislation that condemns unproductive large estates and the need for the land to fulfill a social function. In addition, a provision issued in 2010 prohibits land acquisition by foreigners of landholdings greater than 5000 ha [103]. These provisions will likely not reverse the land inequity incubated for decades.

The recognition of tenure rights through community-based arrangements has simultaneously tried to address claims from local populations to customary rights. Besides the recognition of indigenous territories, as mentioned earlier, several other arrangements have been implemented in Brazil, and the State of Pará, to recognize the rights of a diversity of local actors such as extractivists, peasant farmers, and other traditional populations. Main arrangements are extractive reserves, reserves of sustainable development, and agro-extractive settlements. Unlike conventional schemes of agrarian reform with a stronger focus on agricultural production, these other arrangements tend to grant tenure rights by privileging forest-based livelihoods [3]. In the State of Pará, the total area upon which some type of community-based tenure right has been granted comprises 35.4 million ha (see Table 3 ).

\subsection{Current Land Tenure Administration in Pará}

In 2009, the Legal Tenure Program (labeled "Legal Land") was issued involving the federal and state governments (Federal Law $N^{\circ} 11.952 / 2009$ ). This program put in motion a massive effort towards land tenure regularization. It also encouraged the state government to update laws and processes of land regularization. There are still questions about the political feasibility of a collaborative process to link efforts at different levels of government, which could be able to allocate in a relatively short term lands for smallholders, traditional populations, and quilombolas, as well as recognizing the rights of all indigenous people. To date, several state agencies at the federal state level have responsibilities to intervene in the process of land regularization, including the National Institute of Agrarian Reform, Secretary of Agrarian Planning in the Ministry of Agrarian Development, Chico Mendes Institute for Biodiversity Conservation, National Forestry Service and National Indian Foundation. This diversity of organizations makes it relatively difficult to put in place an effective mechanism for collaboration.

The legal regularization in the State of Pará is linked to broad development aims. Three different efforts have come together: economic-ecological zoning, environmental regulation enforcement, and land regularization. The economic-ecological zoning process, with a state-wide scope, defined road corridors and land-use priority zones (e.g., urban areas, production agriculture zones of lower and higher intensity, forest reserves, protected areas and agrarian reform settlements). In turn, environmental 
enforcement is associated with the Rural Environmental Cadaster (CAR, by its acronym in Portuguese); landholders are compelled to sign an agreement with the state formalizing their commitment to comply with environmental law, mainly to restore forest reserves if required, under the proportions defined under the recently approved Forest Code (Law 12.651, 2012). The Legal Tenure Program in the State of Pará is supposed to grant land ownership or use rights to small- and medium-scale landholders (up to 2500 ha) associated with the measures for environmental licensing previously mentioned. Yet regularization of ownership in landholdings larger than 1500 ha faces more difficulties; claimants must fulfill all legal requirements to be eligible (e.g., proof of five years of occupation, effective use of the land) and obtain permission of the legislative branch to continue this process, which adds more bureaucratic steps.

The measures for achieving "forest-friendly" agricultural production are linked to a new set of constraints and institutional arrangements. In 2009, under pressure from state prosecutors, the National Bank of Development (BNDES, by its acronym in Portuguese) — which accounts for most financing for the agricultural sector in Brazil—began making loans contingent on environmental performance. Furthermore, the major super-market chains also agreed to a moratorium on purchase of meat whose origins were not environmentally certified. The cattle industry in the Brazilian Amazon was targeted, leading major meatpackers and traders to agree to a beef moratorium-based on the 2006 soy moratorium - on deforestation. The industry is now moving quickly to come into compliance with the requirements of the CAR. These two systems of overlapping land information could be interconnected into a single spatial data model. When implemented, this spatial data management model could be used for multiple planning, monitoring, and enforcement purposes. It is expected that the monitoring system will include near real-time tracking of deforestation, like the one implemented in Mato Grosso [104].

With these two new regulations in place linked to parcel-level tenure regularization and monitoring of environmental compliance, important steps have been taken to promote more sustainable agricultural production while simultaneously protecting the forests, in the context of institutional arrangements unfolding at the federal and state levels, while involving municipalities in some cases. While both Legal Land and CAR are still in their infancy, these initiatives constitute very valuable operational strategies for integrating spatial tenure management and land governance because the two are strongly related to each other. Yet there is still a need to link these two initiatives with other ongoing processes, such as state-level territorial planning and efforts towards improving land redistribution, as well as strengthening capacities at municipal levels for effective monitoring and intensification of production systems.

\section{Discussion}

The two previous sections have described the long-term historical processes and current dynamics of land appropriation in lowland Bolivia and the State of Pará in Brazil; these occur in the context of changing environmental policy frameworks whose priority has been to make forest conservation possible. The historical factors shaping land appropriation in these two regions were relatively similar. These factors involved pressure from large-scale agriculture and ranching, accompanied by expansion of smallholders, under contested claims from indigenous people to get their customary rights recognized. Furthermore, environmental concerns in the two regions have also embraced objectives of sustainable forest management and conservation. Yet, the policy approaches to clarifying tenure security in order to tackle associated social and environmental goals have been relatively distinct, although the two cases 
shared relatively similar concerns around ten ure rights regularization, land administration, and forest management. Table 4 below summarizes the main policy approaches adopted by the states in the two cases in line with the main issues of concern on tenure and property rights mentioned in Table 1.

Table 4. Commonalities and differences in policy approaches in Bolivia and Pará.

\begin{tabular}{|c|c|c|}
\hline Key Issues & Lowland Bolivia & State of Pará \\
\hline $\begin{array}{l}\text { Approaches adopted } \\
\text { for clarifying and } \\
\text { securing individual } \\
\text { and collective } \\
\text { property rights }\end{array}$ & $\begin{array}{l}\text { Emphasis on regularizing lands claimed } \\
\text { by communities and individual } \\
\text { landholders. Indigenous lands titled as } \\
\text { Original Community Lands (TCO) with } \\
\text { access, usufruct, and exclusion rights, } \\
\text { but no alienation rights. Large-scale } \\
\text { landholders have to justify FES } \\
\text { compliance that still privileges } \\
\text { agricultural uses as the criteria for } \\
\text { justifying land ownership. } \\
\text { Public lands are registered only after all } \\
\text { community and individual rights have } \\
\text { been clarified, and where no other claims } \\
\text { have been identified. }\end{array}$ & $\begin{array}{l}\text { Emphasis on establishing a system of } \\
\text { conservation units (including } \\
\text { indigenous lands and ResEx), and then } \\
\text { on the regularization of individual and } \\
\text { collective ownership rights. Multiple } \\
\text { types of schemes have been adopted, } \\
\text { with the common denominator that all } \\
\text { of them recognize collective rights with } \\
\text { no alienation rights. There is no legal } \\
\text { procedure to assess the legitimacy of } \\
\text { ownership rights; even those acquired } \\
\text { through semi-legal or illegal means. }\end{array}$ \\
\hline $\begin{array}{l}\text { Mechanisms for } \\
\text { influencing } \\
\text { management of land } \\
\text { and forests in the } \\
\text { landholdings }\end{array}$ & $\begin{array}{l}\text { Medium- and large-scale farmers } \\
\text { required to justify the social and } \\
\text { economic function of the land, to } \\
\text { develop management plans at the farm } \\
\text { level and approve permits for } \\
\text { undertaking forest clearings. All } \\
\text { landholders required to approve } \\
\text { management plans for undertaking } \\
\text { commercial timber extraction. }\end{array}$ & $\begin{array}{l}\text { All landholders are mandated to set } \\
\text { aside } 80 \% \text { of the total forestland in the } \\
\text { farm as legal forest reserve (LFR), and } \\
\text { maintain Areas of Permanent } \\
\text { Preservation (APP). All landholders } \\
\text { have to apply to a Rural Environmental } \\
\text { Cadaster (CAR). Commercial use of } \\
\text { forests requires the approval of } \\
\text { management plans. }\end{array}$ \\
\hline $\begin{array}{l}\text { Measures for affecting } \\
\text { the dynamics } \\
\text { associated with land } \\
\text { appropriation and } \\
\text { frontier expansion }\end{array}$ & $\begin{array}{l}\text { Creation of conservation areas to reduce } \\
\text { the expansion of agriculture into } \\
\text { vulnerable forest ecosystems. Land-use } \\
\text { plans developed with classification of } \\
\text { lands suitable for different land uses. No } \\
\text { measures adopted to reduce the pressures } \\
\text { on frontier expansion resulting from land } \\
\text { regularization and titling that fueled } \\
\text { process of land speculation. }\end{array}$ & $\begin{array}{l}\text { Creation of a mosaic of protected areas } \\
\text { and conservation units in order to limit } \\
\text { the expansion of agricultural frontiers } \\
\text { in areas with high biodiversity value. } \\
\text { Developed economic-ecological zoning } \\
\text { to identify most suitable lands for } \\
\text { different land uses and conservation. } \\
\text { Transparent monitoring and } \\
\text { enforcement of environmental law. }\end{array}$ \\
\hline
\end{tabular}

The main policy goals in Bolivia and Brazil with regards to recognition of collective rights to indigenous people and individual tenure rights, as well as measures for affecting the dynamics associated with land appropriation and frontier expansion, have been relatively similar. Nonetheless, important differences exist with regards to the mechanisms adopted for influencing the management of land and forests in the landholdings. To simplify, the Bolivian government approached land regularization and administration from an agrarian perspective, while the State of Pará adopted a more conservationist 
perspective. In lowland Bolivia, emphasis was given to regularize rights in lands claimed by individuals - from smallholders to large-scale landholders - and communities and indigenous people, as well as identification of public lands occurred only after the recognition of collective and individual rights. In contrast, in Pará, in the context of Brazilian policy, priority was given to the demarcation of conservation units that included indigenous territories and conservation units, and only afterwards tenure rights to indigenous and other traditional communities were granted. In addition, in Brazil, there has recently been a greater emphasis on transparent monitoring of environmental law along with strong enforcement, while in Bolivia a lower level of attention has been given to enforce the law.

\subsection{Approaches for Clarifying and Securing Tenure Rights}

In the two cases, collective rights from indigenous people and traditional communities have been protected, while at the same time, individual rights have been formalized. Community lands in lowland Bolivia occupy $27.5 \%$ and in Pará $28.3 \%$ of the total area. In lowland Bolivia, smallholders-including already titled establishments and those where land regularization has not yet started - would reach about $3.5 \%$ of total area; in Pará, they would reach $21.9 \%$ of total area due to a more systematic process of agrarian reform in Brazil. In lowland Bolivia, 21.1\% of the total area has been titled in favor of medium- and large-scale landholders, yet this proportion could likely increase if land still not regularized is included; in the State of Pará, $27.3 \%$ of the total state area is controlled by large-scale landholders. Still, an unresolved issue is how to deal with public lands that are outside of protected areas and forest concessions. In lowland Bolivia, the approach adopted has favored the occupation of public lands, while in Pará public lands comprise $20 \%$ of the total state area (Tables 2 and 3). In Bolivia, it is expected that all remaining public lands, will be allocated to communities, if current land regulation is applied; it is still uncertain how tenure rights will be granted in public lands in Pará.

In the two cases assessed here, the recognition of tenure rights for indigenous communities has followed a relatively similar approach. In lowland Bolivia, indigenous people have been granted greater autonomy in decision-making of their territories when compared with Pará and the rest of Brazil. In both cases, the states have invested important efforts to demarcate and title the indigenous territories; trying to respect local claims aims to reduce the threat of external actors on these territories. Indigenous people acquired the rights to access, usufruct, manage, and exclude other actors on their territories. The legal frameworks in Brazil recognized collective tenure right for other local populations with some collective tradition to organize access to land and the use of their resources; this occurs through several modalities designed to title community lands. In Bolivia, an adjusted Land Law has stimulated a more proactive titling of community lands, which is also simpler in administrative terms and less expensive.

Land regularization seeking to clarify tenure rights has also contributed to legalize and legitimize medium- and large-scale landholders' land ownership, a portion of which was likely acquired through semi-legal or illegal means. This has been an outcome hard to avoid during land regularization in lowland Bolivia, and will likely occur as well in Pará given existing institutional conditions. In Bolivia, the state introduced a relatively sophisticated criterion and process to determine whether the medium- and large-scale landholdings were complying with their FES. However, since agricultural land uses were given priority, it stimulated forest clearing as the most effective way to justify land ownership. The formalization of rights to medium- and large-scale landholdings is still a major issue in Pará given the 
records of public land encroachment. In addition, while some expropriation has been put in place to make land available for agrarian reform settlements, significant expropriations are not expected in the future. Strong environmental law enforcement in Brazil, however, is leading to a reduction in forest conversion.

Policy approaches for dealing with tenure rights clarification were clearly inspired by notions of neo-classical economics; it was assumed that secure tenure would lead to reduced conflict, while prompting investments towards more sustainable land use. This has not always been the case since in many situations contested tenure rights persist. In these latter cases, it could be important to consider transaction costs involved in legalizing and legitimizing tenure rights as suggested by neo-institutional economic views. The Brazilian and Bolivian experience was a significant attempt to disentangle the different bundles of rights associated with land and forest management in situations where collective rights prevail, thus several schemes for rights recognition have been put in place. Yet while most of rights (e.g., access, usufruct, management, and exclusion) have been granted to local populations, alienation rights are kept in state hands. Furthermore, as suggested by political ecology views, influential local actors have also taken advantage of the land titling process to legitimize their ownership rights.

\subsection{Mechanisms for Influencing Management of Land and Forests}

Environmental regulations have been key in Brazil to advance towards forests conservation and to reduce deforestation. The Forest Crime Law obliges landholders to preserve legal forest reserves in an area equal to $80 \%$ of total landholding in the Amazon. This percent equals $50 \%$ in areas classified for agricultural uses for the ecological and economic zoning. This has been key to forcing landholders to either protect or adopt measures to regenerate forests. Recently, a stronger enforcement of this law, linked to implementation of CAR, has led to significant reduction in forest clearing taking place inside properties [105]. It is still not clear to what extent landholders will comply with these regulations in the long term, a decision linked to the debate about the possibilities of different actors complying with the newly approved Forest Code [106]. It is likely that more stringent environmental regulations in Pará, and in Brazil as a whole, will surely help reduce the impacts of agricultural expansion in deforestation; at the same time, it is likely that those regulations could constrain the land-use choices of smallholders [107].

A quite different approach has been adopted in Bolivia, which has exempted smallholders. It has not been as effective as the Brazilian scheme to protect forests inside landholdings. In Bolivia, landholders have been mandated to implement land use planning at the property level following the broader land-use categories defined in the PLUS at the departmental level. In principle, it was a relatively innovative idea to promote land-use planning at the level of the farm based on a rapid assessment of biophysical potentialities; in practice, it did not work as expected. Many landholders provided an unreliable assessment of the real potential and constraints in their landholdings, and used the policy to justify land conversion instead of helping to protect forest resources. In addition, lack of enforcement for controlling illegal forest clearing made this an ineffective instrument to regulate land use and forest conversion at the farm level. Unfortunately, the Bolivian legislation was not able to put in place an alternative system to stimulate improved land management at the farm level. This is currently one of the major gaps of the law, in a context in which the government attempts to evaluate FES compliance every two years. 
Furthermore, both lowland Bolivia and Brazil have put in place clearer regulations to promote sustainable forest management. These regulations favor the adoption of forest management plans, supported by census and inventories of species to be harvested, which should ensure forest recovery and preserve its environmental functions. Nonetheless, as neo-classical perspectives suggest, the high transaction costs of maintaining forests vis-à-vis other land uses often have not worked in favor of forests, even where clearer tenure rights prevail. In many cases, as indicated by neo-institutional economic views, recognizing tenure rights in favor of communities and smallholders has helped reinforce local norms supporting long-term management perspectives; at the same time, it has contributed to excluding outsiders. Political ecology views regarding the fact that rights are contested over time become weaker in contexts where more tenure rights are exercised and state governments help to enforce them in practice.

\subsection{Measures for Shaping Land Appropriation and Frontier Expansion}

Land regularization efforts increasingly face environmental concerns aimed at supporting a transition towards more sustainable agriculture, which might lower pressure on forests conversion. Nonetheless, neoclassical economics indicates - as illustrated in the two cases - that land regularization combined with lack of incentives for forest conservation can lead to growing pressures on forests. In contrast, under insecure tenure, it is unlikely that economic incentives for forest conservation could work [108]. Thus, states are limited in their possibilities to reduce pressures on forests through incentives and must thus invest in law enforcement to protect public lands. The latter becomes the most effective option to reduce encroachment of public lands, but only where clear mechanisms to identify and register public lands are in place. As political ecology perspectives suggest, the most powerful groups often take advantage and obtain benefits when intense land competition occurs, which is also illustrated in the case examined here.

The Bolivian approach has emphasized land regularization in indigenous lands and individual landholdings, but under a notion of open frontier that has been detrimental to forests and favored influential groups able to secure access to public lands. The main assumption was that public lands might be identified only after other rights on the land were clarified. The latter, in practice, created a rush for land, so that landholders encroached public lands before the arrival of land regularization expecting that their ownership rights would be formalized once the process began. In a complementary trend, landholders with relatively large-scale landholdings also fragmented their properties as a way to reduce the risk of expropriation [67]. Land regularization has also indirectly stimulated forest conversion to agriculture in newly appropriated lands to comply with the FES requirement for productive use [75]. Unfortunately, successive regulations did not introduce any corrective measure to promote the protection of forests in public lands that have slowly been encroached by different groups.

In the State of Pará, land regularization adopted a different perspective, since several actions were enacted to close the agricultural frontier. The main strategy was probably to recognize indigenous territories, and then to create conservation units, including schemes for recognizing individual and collective rights of local populations. The latter limited the possibility of expanding agricultural land uses in areas controlled by individual farming, both small- and large-scale. In addition, the establishment of CAR, promoted by the state, was a key measure contributing to close the agricultural frontier [105]. The conjunction of these different regulations has helped reduce deforestation significantly in new frontier 
lands in the Brazilian Amazon. These measures have been complemented by an economic-ecological zoning process that defines areas where agriculture should expand [107].

\section{Conclusions}

This paper argues that important processes of land appropriation have taken place in the Amazon, which posits an important challenge for land tenure regularization amid objectives of social justice and environmental conservation. We explore two relevant cases: lowland Bolivia in western Amazon and the State of Pará in eastern Amazon. Long-term sustained efforts were undertaken in these cases to clarify tenure rights as a way to promote economic development under broader goals of sustainable development and environmental governance. These two cases offer important lessons to inform the process of achieving land-tenure security within broader environmental governance. The main policy approaches adopted have been inspired by neo-classical and neo-institutional economic assumptions. However, our analysis suggests that political ecology views offer important elements for critically assessing policy frameworks of land regularization. This justifies the importance to move beyond simple economic perspectives on rational choice for assessing tenure and land management, while also embracing more broadly considerations on social inequalities and power relationships. The outcomes from tenure reforms can be understood only by looking at the historical and structural conditions shaping land management and benefits distribution among the different stakeholders involved.

Land occupation and appropriation are long-standing occurrences in the two cases analyzed. They use two contrasting approaches to achieve the main policy goals for tenure rights clarification in the context of changing environmental governance. While Bolivia adopted a more explicit agrarian approach influenced by right-based perspectives to secure land tenure and promote land distribution, Brazil followed a more conservationist approach for securing conservation while still influenced by agrarian reform. In the two cases, important progress has been achieved in improving the legal and institutional architecture to protect local tenure rights and stimulate forest protection. However, a skewed land distribution still persists in both regions, which is difficult to reverse. Furthermore, environmental policy might make life more difficult for smallholders and communities since have to comply with more stringent land tenure and forest management regulations. Learning from each other could be an interesting step forward to secure land tenure and enhance land management, while also supporting environmental governance goals, under approaches that can reach the two goals simultaneously.

Achieving tenure security has been at the core of land and forest management policies implemented in lowland Bolivia and the State of Pará. Land regularization has been inspired by conventional economic views and assumptions. Thus, greater emphasis was given to clarifying land ownership, expecting it would reduce pressures on forests and promote more optimal land uses. The actual processes have not led to those outcomes; they unfolded under relatively complex broader socio-political and institutional conditions that tended to favor those with growing political influence, thus distorting initial goals. Our analysis suggests that growing attention has to be placed in halting encroachment of public lands since it stimulates further land appropriation. Other important issues are differentiating the bundle of rights embedded in property rights in the process of tenure rights recognition; tackling structural factors that impede reversing land concentration; and securing the rights of smallholders and communities over time. Our assessment of tenure regularization adopts a relatively long-term historical 
perspective of land appropriation. This approach offers important potential to assess what works and what does not. It also allows the identification of winners and losers from disparate policy design and implementation, which has strong implications for landscape governance.

\section{Acknowledgments}

A preliminary version of this manuscript was presented at the International Conference on Global Land Grabbing II 17-19 October 2012, organized by the Land Deals Politics Initiative (LDPI) and hosted by the Department of Development Sociology at Cornell University, Ithaca, New York. The authors acknowledge all the comments and suggestions from participants that helped to sharpen the arguments in the current version. Pablo Pacheco acknowledges funding received for this research from the CGIAR Research Program on Forests, Trees and Agroforestry (CRP-FTA). This collaborative program aims to enhance the management and use of forests, agroforestry and tree genetic resources across the landscape from forests to farms. CIFOR leads CRP-FTA in partnership with Bioversity International, CATIE, Agricultural Research for Development (CIRAD), the International Center for Tropical Agriculture and the World Agroforestry Centre.

\section{Author Contributions}

The two authors contributed equally to the development of this manuscript.

\section{Conflicts of Interest}

The authors declare no conflict of interest.

\section{References}

1. Schmink, M.; Wood, C.H. Contested Frontiers in Amazonia; Columbia University Press: New York, NY, USA, 1992; p. 387.

2. Moran, E.F. Private and Public Colonization Schemes in Amazonia. In The Future of Amazonia: Destruction or Sustainable Development? Goodman, D., Hall, A., Eds.; St. Martin's Press: New York, NY, USA, 1990.

3. Pacheco, P.; Barry, D.; Cronkleton, P.; Larson, A. The Recognition of Forest Rights in Latin America: Progress and Shortcomings of Forest Tenure Reforms. Soc. Nat. Resour. 2011, 25, $556-571$.

4. Taylor, P.L.; Larson, A.M.; Stone, S. Forest Tenure and Poverty in Latin America: A Preliminary Scoping Exercise; RRI/CIFOR: Bogor, Indonesia, 2008.

5. Foweraker, J. The Struggle for Land: A Political Economy of the Pioneer Frontier in Brazil from 1930 to the Present Day; Cambridge Latin American Studies: Cambridge, MA, USA, 2002.

6. Alston, L.J.; Libecap, G.D.; Mueller, B. Titles, Conflict, and Land Use: The Development of Property Rights and Land Reform on the Brazilian Amazon. Frontier; University of Michigan Press: Ann Arbor, MI, USA, 1999.

7. Binswanger, H.P. Brazilian policies that encourage deforestation in the Amazon. World Dev. 1991, 19, 821-829. 
8. Thiele, G. The displacement of peasant settlers in the Amazon: The case of Santa Cruz, Bolivia. Hum. Organ. 1995, 54, 273-282.

9. Zimmerer, K.S. Conservation booms, land use transitions and environmental governance in Latin America,1985-2008 (Mexico, Costa Rica, Brazil, Peru, Bolivia). Latin Am. Res. Rev. 2011, 46, 82-114.

10. Pacheco, P.; Aguilar-Støen, M.A.; Börner, J.; Etter, A.; Putzel, L.; Vera-Diaz, M.D.C. Landscape transformation in tropical Latin America: Assessing trends and policy implications for REDD+. Forests 2011, 2, 1-29.

11. Hecht, S.B. Soybeans, development and conservation on the Amazon frontier. Dev. Chang. 2005, 36, 375-404.

12. Pacheco, P. Agricultural expansion and deforestation in Lowland Bolivia: The import substitution versus the structural adjustment model. Land Use Policy 2006, 23, 205-225.

13. Nepstad, D.C.; Stickler, C.M.; Almeida, O.T. Globalization of the Amazon soy and beef industries: Opportunities for conservation. Conserv. Biol. 2006, 20, 1595-1603.

14. Walker, R.; Browder, J.; Arima, E.; Simmons, C.; Pereira, R.; Caldas, M.; Shirota, R.; Zen, S.D. Ranching and the new global range: Amazônia in the 21st century. Geoforum 2009, 40, 732-745.

15. Nelson, M. El Aprovechamiento de las Tierras Tropicales en América Latina; Siglo XXI: Mexico D.F., Mexico; p. 333.

16. Nepstad, D.C.; Stickler, C.M.; Soares-Filho, B.; Merry, F. Interactions among Amazon land use, forests and climate: Prospects for a near-term forest tipping point. Philos. Trans. R. Soc. B 2008, 363, 1737-1746.

17. Pacheco, P. Populist and Capitalist Frontiers in the Amazon: Dynamics of Agrarian and Land-Use Change. Ph.D. Thesis, Clark University, Worcester, MA, USA, 2005.

18. Rudel, T.K.; Defries, R.; Asner, G.P.; Laurance, W.F. Changing drivers of deforestation and new opportunities for conservation. Conserv. Biol. 2009, 23, 1396-1405.

19. Godar, J.; Tizado, E.J.; Pokorny, B.; Johnson, J. Typology and Characterization of Amazon Colonists: A Case Study Along the Transamazon Highway. Hum. Ecol. 2012, 40, 251-267.

20. Pacheco, P. Smallholder livelihoods, wealth and deforestation in the Eastern Amazon. Hum. Ecol. 2009, 37, 27-41.

21. Hecht, S.B. From eco-catastrophe to zero deforestation? Interdisciplinarities, politics, environmentalisms and reduced clearing in Amazonia. Environ. Conserv. 2012, 39, 4-19.

22. Nepstad, D.; McGrath, D.; Soares-Filho, B. Systemic Conservation, REDD, and the Future of the Amazon Basin. Conserv. Biol. 2011, 25, 1113-1116.

23. Anseeuw, W.; Wily, L.A.; Cotula, L.; Taylor, M. Land Rights and the Rush for Land: Findings of the Global Commercial Pressures on Land Research Project; IIED, CIRAD, ILC: Rome, Italy, 2012.

24. Deininger, K.; Feder, G. Land institutions and land markets. In Handbook of Agricultural Economics; Gardner, B., Raussser, G., Eds.; Elsevier North Holland: Amsterdam, The Netherlands, 2001; pp. 288-331.

25. Schneider, R. Government and the Economy on the Amazon; Frontier World Bank Environment Paper No. 11, The World Bank Group: Washington, DC, USA, 1995. 
26. Rudel, T.K.; Bates, D.; Machinguiashi, R. A tropical forest transition? agricultural change, out-migration, and secondary forests in the ecuadorian amazon. Ann. Assoc. Am. Geogr. 2002, 92, 87-102.

27. Eggertsson, T. Economic Behavior and Institutions; Cambridge University Press: Cambridge, UK, 1990; p. 385.

28. North, D.C. Institutions, Institutional Change and Economic Performance; Cambridge University Press: Cambridge, UK, 1990; p. 152.

29. Williamson, O.E. Transaction-Cost Economics: The Governance of Contractual Relations. J. Law Econ. 1979, 22, 233-261.

30. Rao, P.K. The Economics of Transaction Costs; Palgrave: Macmillan, UK, 2003.

31. Schlager, E.; Ostrom, E. Property-rights regimes and natural resources: A conceptual analysis. Land Econ. 1992, 68, 249-262.

32. Agrawal, A.; Ostrom, E. Collective Action, Property Rights, and Decentralization in Resource Use in India and Nepal. Polit. Soc. 2001, 29, 485-514.

33. Ascher, W. Communities and Sustainable Forestry in Developing Countries; ICS Press: San Francisco, CA, USA, 1995; p. 177.

34. Baland, J.-M.; Platteau, J.-P. Halting Degradation of Natural Resources: Is There a Role for Rural Communities? Clarendon Press: Oxford, UK, 1996; p. 440.

35. Dietz, T.; Stern, P.C.; Ostrom, E. Struggling the commons. Science 2003, 302, 1907-1012.

36. Gibson, C.; Williams, J.; Ostrom, E. The Importance of Rule Enforcement for Local-Level Forest Management; Reconciling Rural Poverty Reduction and Resource Conservation: Ithaca, New York, NY, USA, 1-4 May 2003.

37. Gibson, C.C.; Ostrom, E.; MacKean, M.A. Forests, People, and Governance: Some Initial Theoretical Lessons. In People and Forests: Communities, Institutions and Governance; Gibson, C.C., Ostrom, E., MacKean, M.A., Eds.; The MIT Press: Cambridge, MA, USA, 2000; pp. 227-242.

38. Ostrom, E. The Rudiments of a Theory of the Origins, Survival, and Performance of Common-Property Institutions. In Making the Commons Work; Bromley, D.W., Ed.; Institute for Contemporary Studies Press: San Francisco, CA, USA, 1992; pp. 293-318.

39. Benjaminsen, T.; Lund, C.; Holden, S.; Sjaastad, E. Formalisation of land rights: Some empirical evidence from Mali, Niger and South Africa. Land Use Policy 2008, 26, 28-35.

40. Sikor, T.; Müller, D. The limits of state-led land reform: An introduction. World Dev. 2009, 37, 1307-1316.

41. Colin, J.-P. Securing rural land transactions in Africa. An Ivorian perspective. Land Use Policy 2013, 31, 430-440.

42. Pacheco, P. Estilos de Desarrollo, Deforestación y Degradación de los Bosques en las Tierras Bajas de Bolivia; CEDLA, TIERRA, CIFOR: La Paz, Bolivia, 1998; p. 389.

43. Fifer, J.V. The Empire Builders: A History of the Bolivian Rubber Boom and the Rise of the House of Suarez. J. Latin Am. Stud. 1970, 2, 113-146.

44. Pacheco, P. Integración Económica y Fragmentación Social: El Itinerario de las Barracas en la Amazonia Boliviana; Centro de Estudios para el Desarrollo Laboral y Agrario (CEDLA): La Paz, Bolivia, 1992; p. 295. 
45. Mather, K.F. Exploration in the land of the Yuracares, eastern Bolivia. Geogr. Rev. 1922, 12, 42-56.

46. Arrieta, M.; Abrego, G.; Castillo, A.; de la Fuente, M. Agricultura en Santa Cruz: De la Encomienda Colonial a la Empresa Modernizada (1559-1985); Instituto Latinoamericano de Investigación Social: La Paz, Bolivia, 1990; pp. 374.

47. Romero, C. La Reforma Agraria en las Tierras Bajas de Bolivia. Artíc. Prim. 2003, 7, 53-84.

48. Dandler, J. El desarrollo de la agricultura, políticas estatales y el proceso de acumulación en Bolivia. Estud. Rural. Latinoam. 1984, 7, 81-149.

49. Pacheco, P.; de Jong, W.; Johnson, J. The evolution of the timber sector in lowland Bolivia: Examining the influence of three disparate policy approaches. For. Policy Econ. 2010, 12, 271-276.

50. Eastwood, D.; Pollard, H. The Development of Colonization in Lowland Bolivia: Objetives and Evaluation. Bol. Estud. Latinoam. Caribe 1985, 38, 61-83.

51. Blanes, J.; Calderón, F.; Dandler, J.; Prudencio, J.; Lanza, L. Migración Rural: El Caso de las colonias. In Tras Nuevas Raíces. Migraciones Internas y Colonización en Bolivia; Ministerio de Planeamiento-FNUAP: La Paz, Bolivia, 1985.

52. Urioste, M. Segunda Reforma Agraria: Campesinos, Tierra y Educación Popular; CEDLA: La Paz, Bolivia, 1988; p. 291.

53. Hunnisett, G. The Forest Sector and Deforestation in Bolivia; The World Bank: La Paz, Bolivia, 1996.

54. Quiroga, M.S.; Salinas, E. Minerales y Madera, Temas para el Debate Ambiental; Grupo de Acción y Reflexión sobre el Medio Ambiente: La Paz, Bolivia, 1996.

55. Navia, C. Nuestro Bosque de Mañana. Síntesis Documental del Proceso Forestal Beniano 1979-1988; Instituto Latinoamericano de Investigación Social (ILDIS): La Paz, Bolivia, 1989.

56. Kaimowitz, D.; Graham, T.; Pacheco, P. The effects of structural adjustment on deforestation and forest degradation in lowland Bolivia. World Dev. 1999, 27, 505-520.

57. Kaimowitz, D.; Smith, J. Soybean technology and the loss of natural vegetation in Brazil and Bolivia. In Agricultural Technologies and Tropical Deforestation; Angelsen, A., Kaimowitz, D., Eds.; CABI Publishing: New York, NY, USA, 2001.

58. Bojanic, A. Balance is Beautiful: Assessing Sustainable Development in the Rain Forest of the Bolivian Amazon PROMAB Scientific Series No. 1; CIFOR, University of Utrecht and PROMAB: Utrecht, The Netherlands, 2001; p. 256.

59. Beltrán, J.; Phillips, A. Indigenous and Traditional Peoples and Protected Areas: Principles, Guidelines and Case Studies; World Commission on Protected Areas (WCPA): Cambridge, United Kingdom, 2000.

60. Taylor, G.; Nittler, J.; Kraljevic, I. Global Initiatives, Public Policies and Private Forestry in Bolivia: Lessons to Date and Remaining Challenges. In Forest Policy for Private Forestry; Teeter, L.D., Cashore, B., Zhang, D., Eds.; CABI Publishing: Wallingford Oxon, UK, 2002.

61. Pacheco, P. El nuevo régimen forestal boliviano: Una mirada retrospectiva a diez años de su implementación. Recur. Nat. Ambient. 2007, 49, 58-67.

62. Urioste, M.; Pacheco, D. Las Tierras Bajas a Fines del Siglo XX; Proyecto de Investigaciones Estratégicas: La Paz, Bolivia, 2001; p. 437. 
63. Benneker, C. Dealing with the State, the Market and NGOs: The Impact of Institutions on the Constitution and Performance of Community Forest Enterprises (CFE) in the Lowlands of Bolivia; Wageningen University: Wageningen, The Netherlands, 2008.

64. ABT. Informe Anual 2010 y Balance de la Década; Autoridad de Fiscalizacion y Control Social de Bosques y Tierra: Santa Cruz, Bolivia, 2011.

65. Balderrama, C. Estadisticas Agrarias: Tenencia de la Tierra en Bolivia (1953-2002); Instituto Nacional de Reforma Agraria, Embajada Real de Dinamarca-Programa Sectorial de Apoyo a los Pueblos Indígenas: La Paz, Bolivia, 2002.

66. Hernáiz, I.; Pacheco, D. La Ley INRA en el Espejo de la Historia: Dos Siglos de Reformas Agrarias en Bolivia; Fundación TIERRA: La Paz, Bolivia, 2000; p. 127.

67. Urioste, M. Concentracion y Extranjerizacion de la tierra en Bolivia; Fundacion Tierra: La Paz, Bolivia, 2011.

68. Pattie, P.; Rojas, P. Análisis de la Patente Forestal por Superficie; Proyecto de Manejo Forestal Sostenible BOLFOR: Santa Cruz, Bolivia, 2003.

69. Pacheco, P. Towards a Forestry Strategy in Bolivia: Helping Forests to Help People. Report to FAO; FAO: Rome, Italy, 2005.

70. Cronkleton, P.; Pacheco, P. Changing Policy Trends in the Emergence of Bolivia's Brazil Nut Sector. In Wild Product Governance: Finding Policies that Work for Non-Timber Forest Products; Laird, S., McLain, R., Wynberg, R., Eds.; Earthscan: London, UK, 2010.

71. Pacheco, P. What Lies behind Decentralization? Forest, Powers and Actors in Lowlands Bolivia. Eur. J. Dev. Res. 2004, 16, 90-109.

72. Pacheco, P. Descentralización Forestal en Bolivia: Implicaciones en el Gobierno de los Recursos Forestales y el Bienestar de los Grupos Marginados; CIFOR/IDRC: La Paz, Bolivia, 2006.

73. Pacheco, P. Acceso y uso de la Tierra y Bosques en Bolivia: Sus Implicaciones Para el Desarrollo y la Conservación; UDAPE: La Paz, Bolivia, 2006.

74. Andaluz, A. Los Conceptos Claves de Estado y los Planes de Ordenamiento Predial-POP; Proyecto de Manejo Forestal Sostenible, BOLFOR: Santa Cruz, Bolivia, 1998.

75. Müller, R.; Pacheco, P.; Montero, J.C. The Context of Deforestation and Forest Degradation in Bolivia: Drivers, Agents and Institutions; CIFOR: Bogor, Indonesia, 2014.

76. INRA. Informe de Gestión 2010; Instituto Nacional de Reforma Agraria: La Paz, Bolivia, 2011.

77. Weinstein, B. A Borracha na Amazonia: Expansao e Decadencia 1850-1920; Editora Hucitec, Editora da Universidade de Sao Paulo: Sao Paulo, Mexcio, 1993; p. 371.

78. Ianni, O. A Luta pela Terra: Historia Social da Terra e da Luta pela Terra numa Area da Amazonia, 2nd ed.; Vozes: Petropolis, RJ, USA, 1979; p. 235.

79. Baer, W. The Brazilian Economy: Growht and Development; Praeger Publishers: Westport, CT, USA, 2001; p. 498.

80. Treccani, G.D. Violência e Grilagem: Instrumentos de Aquisição da Propriedade da Terra no Pará; UFPA, ITERPA: Belém, Brazil, 2001; p. 348.

81. Hecht, S.; Cockburn, A. The Fate of the Forest: Developers, Destroyers and Defenders of the Amazon; Verso: London, UK, 1989; p. 266.

82. Cleary, D. After the Frontier: Problems with Political Economy in the Modern Brazilian Amazon. Latin Am. Stud. 1993, 25, 331-349. 
83. Eleres, P. Intervenção Territorial Federal na Amazônia; Imprensa oficial do Estado: Belem, Brazil, 2002; p. 145.

84. Schneider, R. Land Abandonment, Property Rights, and Agricultural Sustainability in the Amazon; Dissemination Note No. 3, World Bank: Washington, DC, USA, 1993.

85. Monteiro, M.D.A. Meio século de mineração industrial na Amazônia e suas implicações para o desenvolvimento regional. Estud. Av. 2005, 19, 187-207.

86. Benatti, J.H. Direito de Propriedade e Proteção Ambiental no Brasil: Apropriação e uso dos Recursos Naturais no Imóvel Rural; Universidade Federal do Para: Belem, Brasil, 2003.

87. Le Tourneau, F.-M.; Droulers, M. Amazonia, la fin de la frontière. Caravelle Cahiers Monde Hisp. Luso-Brés. 2000, 75, 109-135.

88. Moran, E.F. Colonization in the Transamazon and Rondônia. In Frontier Expansion in Amazonia; Schmink, M., Wood, C.H., Eds.; University of Florida Press: Gainesville, FL, USA, 1984; pp. 285-303.

89. Hecht, S. The economics of cattle ranching in eastern Amazonia. Interciencia 1988, 13, 233-240.

90. Pacheco, P. Revisiting the Role of Fiscal Incentives on Driving Livestock Expansion in the Brazilian Amazon; The World Bank Group: Brasilia, Brazil, 2002.

91. Kohlhepp, G. Problemas do Planejamento Regional e do Desenvolvimento Regional na Área do Programa Grande Carajás no Leste da Amazônia. In Homem e natureza na Amazônia; Kohlhepp, G., Schrader, A., Eds.; BPR Publishers: Tübingen, Germany, 1987; pp. 313-345.

92. Pacheco, P. Agrarian change, cattle ranching and deforestation: Assessing their linkages in southern Para. Environ. Hist. 2009, 15, 493-520.

93. Castro, E.; Moura, E.A.F.; Maia, M.L.S. Industrializacão e Grandes Projetos: Desorganizacão e Reorganizacão do Espaço; Universidade Federal do Para: Belem, Brasil, 1995; p. 410.

94. Hecht, S. The logic of livestock and deforestation in Amazonia. Bioscience 1993, 43, 687-695.

95. Becker, B. Condição do Desenvolvimento Sustentável da Amazônia. In $4^{\text {a }}$ Conferência Nacional de Ciência, Tecnologia e Inovação para o Desenvolvimento Sustentável, Brasília, Brazil, 2010.

96. Kohlhepp, G. A Amazônia frente a um novo desafio: O desenvolvimento sustentável e o programa Avança Brasil. Amazônia: Avança o Brasil? Cad. Adenauer 2001, 2, 9-38.

97. Killeen, T. A Perfect Storm in the Amazon. Wilderness: Development and Conservation in the Context of the Initiative for the Integration of Regional Infrastructure of South. America (IIRSA); Conservation International: Washington, DC, USA, 2007.

98. Simmons, C.; Walker, R.; Arima, E.; Aldrich, S.; Caldas, M. The Amazon Land War in the South of Pará. Ann. Assoc. Am. Geogr. 2007, 97, 567-592.

99. ISA. De Olho nas Terras Indigenas; Instituto Socioambiental: Belem, Brazil, 2012.

100. ITERPA. Relatório de Gestão 2010 e Análise do Periodo 2007-2010; Instituto de Terras do Para: Belem, Brazil, 2010.

101. INCRA. National Institute of Agrarian Reform; INCRA: Brasília, Brazil, 2010.

102. Pacheco, P. Agrarian Reform in the Brazilian Amazon: Its Implications for Land Distribution and Deforestation. World Dev. 2009, 37, 1337-1347. 
103. Peduzzi, P. AGU limita venda de terras brasileiras a empresas controladas por estrangeiros. In Agência Brasil, 2010. Available online: http://agencia-brasil.jusbrasil.com.br/noticias/2342554/ agu-limita-venda-de-terras-brasileiras-a-empresas-controladas-por-estrangeiros (accessed on 15 September 2012).

104. Souza, J.; Carlos M.; Haiashy, S.; Verissimo, A. Deforestation alerts for forest law enforcement: The case of Mato Grosso, Brazil. In Proceedings of the Annual Conference on Land Policy and Administration, Washington, DC, USA, 2010.

105. Nepstad, D.; McGrath, D.; Stickler, C.; Alencar, A.; Azevedo, A.; Swette, B.; Bezerra, T.; DiGiano, M.; Shimada, J.; da Motta, R.S.; et al. Slowing Amazon deforestation through public policy and interventions in beef and soy supply chains. Science 2014, 344, 1118-1123.

106. Soares-Filho, B.; Rajão, R.; Macedo, M.; Carneiro, A.; Costa, W.; Coe, M.; Rodrigues, H.; Alencar, A. Cracking Brazil's Forest Code. Science 2014, 344, 363-364.

107. Börner, J.; Wunder, S.; Wertz-Kanounnikoff, S.; Hyman, G.; Nascimento, N. Forest law enforcement in the Brazilian Amazon: Costs and income effects. Glob. Environ. Chang. 2014, 29, 294-305.

108. Wunder, S. The efficiency of payments for environmental services in tropical conservation: Essays. Conserv. Biol. 2007, 21, 48-58.

(C) 2015 by the authors; licensee MDPI, Basel, Switzerland. This article is an open access article distributed under the terms and conditions of the Creative Commons Attribution license (http://creativecommons.org/licenses/by/4.0/). 